\title{
TRANSCORTIN: A CORTICOSTEROID-BINDING PROTEIN OF PLASMA. III. THE EFFECTS OF VARIOUS STEROIDS * $\dagger$
}

\author{
By AVERY A. SANDbERG, W. ROY SLAUNWHite, Jr. and ANNE C. CARTER \\ (From the Roswell Park Memorial Institute, Buffalo, N. Y. and the Department of Medicine, \\ State Uniwersity of New York, College of Medicine at New York City, N. Y.)
}

(Submitted for publication June 21, 1960 ; accepted August 11, 1960)

In previous publications $(1,2)$ we have described some of the characteristics of transcortin, a plasma protein (or proteins) with high affinity for cortisol and corticosterone. In addition, we have shown that plasma transcortin levels are elevated during pregnancy and following administration of estrogens (1-3). A different interpretation of the findings in these two states has been given by Daughaday and Mariz $(4,5)$. Transcortin levels were substantially lower in the plasma of newborn infants (umbilical vein blood) than those found in adult subjects or in older children (2). The purpose of this paper is to present results of further studies on transcortin levels in human sub-

* This investigation was supported in part by grants (A-1240-C3) from the National Institute of Arthritis and Metabolic Diseases and from the National Cancer Institute (CY-3601), Bethesda, Md.

$\dagger$ The following abbreviations have been employedcortisol : $11 \beta, 17 \alpha, 21$-trihydroxy - 4 -pregnene-3,20-dione ; dihydrocortisol $\left(\mathrm{H}_{2} \mathrm{~F}\right)$ : $11 \beta, 17 \alpha, 21$-trihydroxy-pregnane3,20-dione; tetrahydrocortisol $\left(\mathrm{H}_{4} \mathrm{~F}\right): 3 \alpha, 11 \beta, 17 \alpha, 21-$ tetrahydroxy-pregnane-20-one; $9 \alpha$-fluorocortisol: $9 \alpha$ fluoro-11 $\beta, 17 \alpha, 21$-trihydroxy-4-pregnene-3,20-dione ; cortisone : $17 \alpha, 21$-dihydroxy - 4 -pregnene-3,11,20-trione; di hydrocortisone $\quad\left(\mathrm{H}_{2} \mathrm{E}\right)$ : $17 \alpha, 21$-dihydroxy-pregnane$3,11,20$-trione; tetrahydrocortisone $\left(\mathrm{H}_{4} \mathrm{E}\right): 3 \alpha, 17 \alpha$, 21-trihydroxy-pregnane-11,20-dione; corticosterone: $11 \beta$, 21-dihydroxy-4-pregnene-3,20-dione; aldosterone: $11 \beta, 21$ dihydroxy-18-aldo-4-pregnene-3,20-dione: Compound $\mathrm{S}$ (11-deoxycortisol) : 17 $\alpha, 21$-dihydroxy-4-pregnene-3,20-dione ; $6 \alpha$-methylprednisolone : $6 \alpha$-methyl-11 $\beta, 17 \alpha-21$-trihydroxy-1,4-pregnadiene-3,20-dione; $17 \alpha$-hydroxyprogesterone $(17-\mathrm{OHPg})$ : $17 \alpha$-hydroxy-4-pregnene-3,20-dione ; $\Delta^{4}$-androstenedione: 4 -androstene-3,17-dione; $17 \alpha$-methyl19-nortestosterone: $17 \alpha$-methyl-17 $\beta$-hydroxy-4-estrene-3one ; testosterone propionate : $17 \beta$-propionoxy-4-androsten3 -one; $2 \alpha$-methyl-dihydrotestosterone propionate: $2 \alpha$ methyl-17 $\beta$-propionoxy-androstan-3-one; estriol: $1,3,5$ (10)-estratriene-3, 16 $\alpha, 17 \beta$-triol ; $16 \alpha$-estradiol dipropionate: $1,3,5(10)$-estratriene-3,16 $\alpha$-dipropionate; Estinyl : $17 \alpha$-ethinyl-3,17 $\beta$-dihydroxy-1,3,5(10)-estratriene; stilbestrol : 3,4-bis ( $p$-hydroxyphenyl) -3-hexene ; Premarin : conjugated equine estrogens, containing approximately 90 per cent estrone sulfate; ACTH: adrenocorticotropin. jects under various conditions and the effects of administered steroids on these levels.

\section{METHODS AND MATERIALS}

The binding of $\mathrm{C}^{14}$-cortisol by plasma transcortin and the transcortin capacity were determined by methods previously described $(1,2)$. The terms "transcortin binding of $\mathrm{C}^{14}$-cortisol" and "transcortin capacity" have been defined in a previous publication (2). At this point it may be appropriate to reiterate some important aspects of the methodologies and terms used. Most of the binding experiments were performed by dialyzing $10 \mathrm{ml}$ of diluted plasma ( $1: 5$ with physiological saline) against 30 $\mathrm{ml}$ of saline containing approximately $0.3 \mathrm{mg}$ of $\mathrm{C}^{14}$ cortisol. The binding was determined with and without the addition of $1 \mu \mathrm{g}$ of cortisol to the saline in order to measure the decrease in the binding caused by the addition of the carrier cortisol. In previously published work (1) we demonstrated that under the conditions of our assay the binding of cortisol by plasma was essentially due to transcortin and not to other plasma proteins. Hence, the term "transcortin binding of $\mathrm{C}^{14}$-cortisol" will refer to the percentage of $\mathrm{C}^{14}$-cortisol bound by $10 \mathrm{ml}$ of diluted plasma and the term "transcortin capacity" will be used to indicate the decrease in binding caused by the addition of $1 \mu \mathrm{g}$ of cortisol in the dialysis conditions outlined above. It should be pointed out that the "binding capacity" will be inversely related to the decrease in the binding caused by the addition of $1 \mu \mathrm{g}$ of cortisol to normal plasma, i.e., the less the decrease in the binding the higher the binding capacity, and vice versa. The measurement of the binding capacity by the method outlined above seems to offer, at the moment, the most practical and sensitive index of transcortin capacity. It should be realized, however, that this measures the difference between two variables, the level of transcortin and the level of 17-hydroxycorticosteroids (17-OHCS).

Lymph was collected from the thoracic ducts of patients with advanced cancer in ice-chilled bottles and diluted $1: 5$ with saline for the determination of the binding of $\mathrm{C}^{14}$-cortisol. The lymph used constituted an aliquot of a 24 hour specimen, whereas the binding of plasma was determined on blood obtained between 8 and 11 a.m. The 17-OHCS levels were determined by the method of Peterson, Karrer and Guerra (6). Blood from postoperative patients was obtained in the recovery room, usually 30 to 60 minutes after completion of the operation. The control samples on the same patients were drawn 
several days preoperatively. The plasma and lymph samples were frozen whenever shipped or stored. The erythrocytes were separated from the plasma by centrifugation. The plasma and the upper layer of the red blood cells were removed by aspiration. The erythrocytes were then washed three times with three volumes of physiological saline, the cells being spun down after each washing.

The $\mathrm{C}^{14}$-labeled dihydro- and tetrahydrocortisone acetates were converted to the free alcohols by incubation with acetyl cholinesterase.

In the double equilibrium dialysis the technique of Daughaday, Mariz, Kozak and Biederman was followed $(5,7)$. Thus, under these conditions, the different plasmas (from normal subjects, patients receiving estrogens, and pregnant women), and the transcortin therein, were made to compete not only for the added $\mathrm{C}^{14}$-cortisol, but also for the endogenous cortisol present in the plasmas. In addition, the binding exhibited by the same plasmas (diluted and undiluted) was determined by methods described previously (2).

\section{RESULTS}

For a better understanding of the results to be presented, it may be worthwhile to discuss briefly some of the salient features of the binding of transcortin and cortisol. In Figure 1 are shown two representative curves based on data obtained in our laboratory. At low cortisol concentrations the transcortin in normal plasma will bind the steroid almost quantitatively, resulting in the left plateaulike part of the "control" curve. When the concentration of transcortin is increased (e.g., following estrogen administration) the plateau is extended to the right, as in the "test" curve. In addition, when the concentration of cortisol is increased the resultant decrease in the binding (which we call "transcortin capacity") will be smaller in the "test" plasma than in the "control" one. With increasing concentrations of cortisol a sigmoid curve is obtained, ending in a plateau-like right shoulder of the curves. In most of the studies to be reported the determination of transcortin binding was associated with the left half of the curve, with the result that small decreases in binding, upon the addition of $1 \mu \mathrm{g}$ of cortisol in the standard test, indicated an increased transcortin capacity. In a few studies (surgical stress, ACTH and cortisol administration) the determinations were associated with the lower right half of the curve with the result that the binding of $\mathrm{C}^{\mathbf{1 4}}$-cortisol in the standard test was already low and the decrease in binding upon the addition

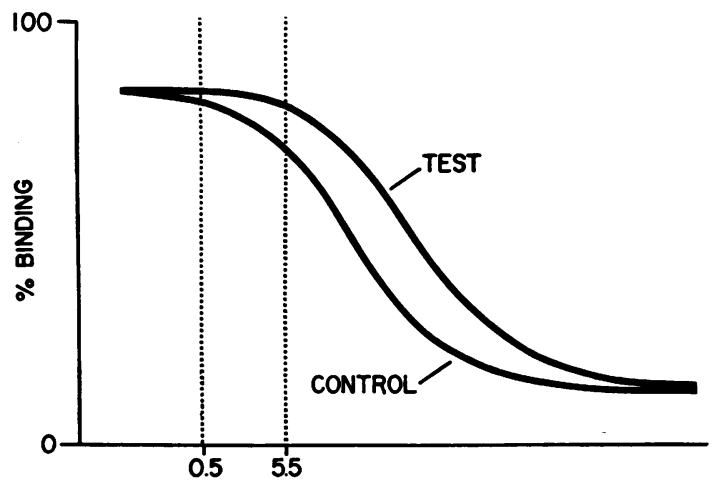

TOTAL AMOUNT OF CORTISOL IN $\mu g$.

Fig. 1. Curves FOR the BINDING OF CORTISOL BY TRANSCORTIN. The "test" curve is applicable to plasma obtained from subjects receiving estrogen therapy and containing an increased transcortin concentration. The "control" curve applies to plasma of normal subjects. When $0.5 \mu \mathrm{g}$ of cortisol is present, the binding by the transcortin in the "control" plasma is only slightly lower than that in the "test" plasma. At a concentration of 5.5 $\mu \mathrm{g}$ of cortisol, however, the binding by the cortisol plasma is considerably lower than that of the "test" plasma, indicating a lower transcortin capacity in the former plasma than in the latter. At very high concentrations of cortisol (right side of the curve) the differences in the transcortin binding between the two plasmas are again slight.

of $1 \mu \mathrm{g}$ of cortisol was small. In this case, even though the decrease in the percentage of $\mathrm{C}^{14}$-cortisol bound was small, a reduced transcortin capacity is indicated. As yet, we know little about conditions which may be accompanied by changes in the shape of the sigmoid curves, either shortening or lengthening the vertical and/or horizontal distances between the two plateaus. Until the actual concentration of transcortin can be determined or the protein isolated, this aspect of transcortin remains a perplexing problem.

Transcortin levels in normal subjects and in women with cancer. During this study the transcortin binding of $\mathrm{C}^{14}$-cortisol exhibited by the plasmas of 14 normal subjects was $90 \pm 2.8$ per cent and the transcortin capacity was $21 \pm 3.3$ per cent. The group of normal subjects included 7 females and 7 males (ages 22 to 45 years) with a mean plasma 17-OHCS level of $5 \pm 4 \mu \mathrm{g}$ per $100 \mathrm{ml}$. The values for transcortin binding of $\mathrm{C}^{14}$ cortisol and capacity for the normal subjects in the present study are slightly higher than those reported by us previously ( $84 \pm 12.4$ per cent) 
for another group of 10 normal subjects (2). The most likely explanation for these differences may be the fact that the bloods in the present study were drawn mostly between 8 and 10 a.m., whereas in the previous study the bloods were obtained in the afternoon. Since the plasma 17-OHCS are known to be higher and to vary more in the afternoon than in the morning, one might expect lower binding of $\mathrm{C}^{14}$-cortisol with more spread in the binding values with such plasmas.
Three groups of postmenopausal women were studied. In a group (I) of 20 women (age range 35 to 80 ) with advanced breast cancer, seen by one of us in New York City, the mean values ( $\pm \mathrm{SD}$ ) were: transcortin binding of $\mathrm{C}^{14}$-cortisol, $95 \pm 3.3$ per cent ; transcortin capacity, $21 \pm 5.6$ per cent; and the plasma 17-OHCS levels, $20 \pm$ $7 \mu \mathrm{g}$ per $100 \mathrm{ml}$. In another group (II) of 16 women (ages 32 to 72), who had undergone surgery of the breast for cancer at least three years

TABLE I

Changes in transcortin binding of $C^{14}$-cortisol and capacity during estrogen and/or testosterone therapy

\begin{tabular}{|c|c|c|c|c|c|c|}
\hline Subject, diagnosis & $\begin{array}{l}\text { Sex, } \\
\text { Age }\end{array}$ & Therapy & $\begin{array}{l}\text { Days } \\
\text { following } \\
\text { beginning } \\
\text { of therapy }\end{array}$ & $\begin{array}{l}\mathrm{C}^{14}- \\
\text { cortisol } \\
\text { bound }\end{array}$ & $\begin{array}{l}\text { Binding } \\
\text { capacity }\end{array}$ & $\begin{array}{l}\text { Plasma } \\
17- \\
\text { OHCS }\end{array}$ \\
\hline $\begin{array}{l}\text { S.R. } \\
\text { Carcinoma of prostate }\end{array}$ & $\begin{array}{l}\mathrm{M} \\
59\end{array}$ & $\begin{array}{l}\text { Stilbestrol } 5 \mathrm{mg} 3 \text { times } \\
\text { daily from Days } 1-40\end{array}$ & $\begin{array}{r}0 \\
0 \\
2 \\
4 \\
6 \\
8 \\
12 \\
15 \\
20 \\
25 \\
32 \\
39 \\
48\end{array}$ & $\begin{array}{l}\% \\
86 \\
87 \\
88 \\
92 \\
94 \\
92 \\
94 \\
94 \\
93 \\
94 \\
96 \\
98 \\
94\end{array}$ & $\begin{array}{l}\% \\
19 \\
25 \\
20 \\
19 \\
16 \\
11 \\
14 \\
14 \\
13 \\
11 \\
11 \\
11 \\
11\end{array}$ & $\begin{array}{c}\mu g \% \\
24 \\
16 \\
27 \\
26 \\
28 \\
41 \\
29 \\
32 \\
45 \\
44 \\
46 \\
40 \\
43\end{array}$ \\
\hline $\begin{array}{l}\text { J.E. } \\
\text { Hodgkin's disease }\end{array}$ & $\begin{array}{l}F \\
42\end{array}$ & $\begin{array}{c}\text { Stilbestrol } 5 \mathrm{mg} 3 \text { times } \\
\text { daily from Days } 1-6\end{array}$ & $\begin{array}{r}0 \\
0 \\
1 \\
2 \\
3 \\
4 \\
6 \\
8 \\
10 \\
13 \\
15 \\
21\end{array}$ & $\begin{array}{l}81 \\
88 \\
90 \\
94 \\
95 \\
93 \\
98 \\
91 \\
92 \\
91 \\
91 \\
92\end{array}$ & $\begin{array}{l}21 \\
21 \\
20 \\
16 \\
15 \\
17 \\
17 \\
13 \\
15 \\
17 \\
17 \\
18\end{array}$ & $\begin{array}{l}27 \\
20 \\
32 \\
46 \\
34 \\
56 \\
44 \\
44 \\
33 \\
28 \\
24 \\
16\end{array}$ \\
\hline $\begin{array}{l}\text { F.P. } \\
\text { Carcinoma of breast }\end{array}$ & $\begin{array}{l}\mathrm{F} \\
54\end{array}$ & $\begin{array}{l}\text { Premarin orally } 10 \mathrm{mg} \\
\text { daily for } 14 \text { days }\end{array}$ & $\begin{array}{r}0 \\
2 \\
4 \\
7 \\
10 \\
14 \\
17 \\
21 \\
28\end{array}$ & $\begin{array}{l}86 \\
90 \\
92 \\
96 \\
98 \\
98 \\
92 \\
88 \\
88\end{array}$ & $\begin{array}{l}24 \\
20 \\
18 \\
12 \\
12 \\
12 \\
14 \\
20 \\
22\end{array}$ & $\begin{array}{r}11 \\
11 \\
17 \\
28 \\
34 \\
36 \\
30 \\
22 \\
7\end{array}$ \\
\hline $\begin{array}{l}\text { M.W. } \\
\text { Carcinoma of breast }\end{array}$ & $\begin{array}{l}F \\
62\end{array}$ & $\begin{array}{l}\text { Testosterone propionate } \\
50 \mathrm{mg} \text { i.m. from Days } \\
1-14 \text {; stilbestrol } 5 \mathrm{mg} \\
3 \text { times daily from } \\
\text { Days } 7-14\end{array}$ & $\begin{array}{r}0 \\
7 \\
10 \\
14\end{array}$ & $\begin{array}{l}94 \\
92 \\
99 \\
99\end{array}$ & $\begin{array}{r}26 \\
24 \\
12 \\
7\end{array}$ & $\begin{array}{r}4 \\
17 \\
13 \\
33\end{array}$ \\
\hline $\begin{array}{l}\text { M.S. } \\
\text { Carcinoma of breast }\end{array}$ & $\begin{array}{l}F \\
65\end{array}$ & $\begin{array}{l}\text { Testosterone propionate } \\
50 \mathrm{mg} \text { i.m. daily for } \\
5 \text { days }\end{array}$ & $\begin{array}{r}0 \\
1 \\
3 \\
4 \\
5 \\
7 \\
15 \\
18\end{array}$ & $\begin{array}{l}80 \\
84 \\
82 \\
82 \\
92 \\
87 \\
92 \\
96\end{array}$ & $\begin{array}{l}19 \\
19 \\
21 \\
21 \\
26 \\
24 \\
22 \\
25\end{array}$ & $\begin{array}{r}8 \\
8 \\
8 \\
8 \\
13 \\
7 \\
1\end{array}$ \\
\hline
\end{tabular}




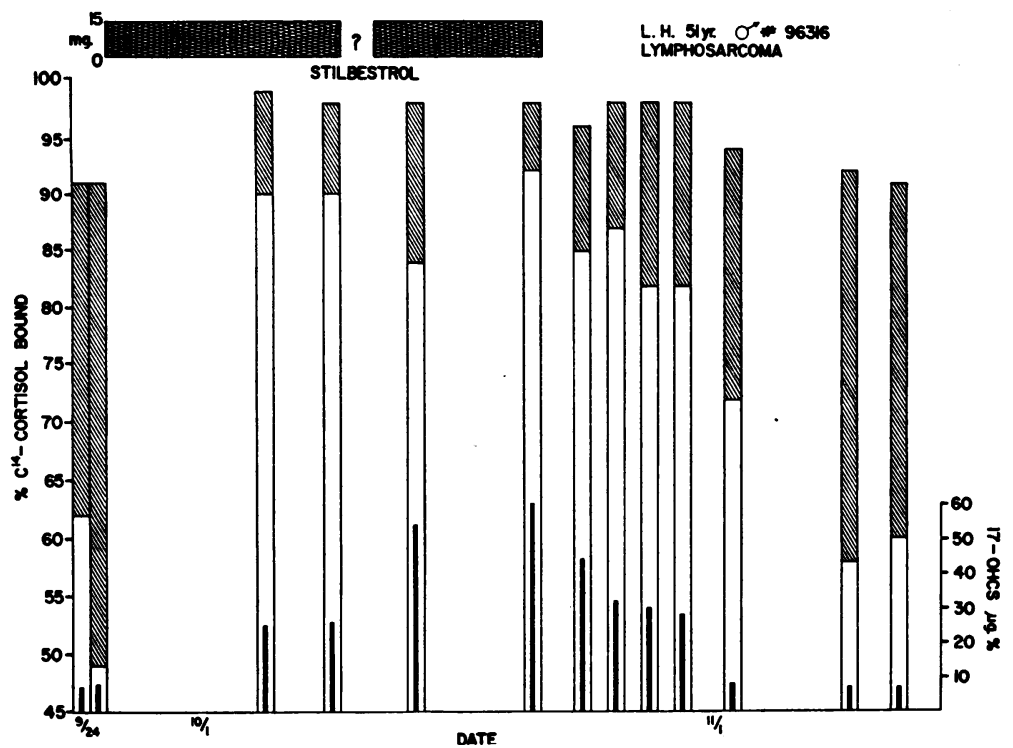

Fig. 2. Changes in transcortin Binding of C $C^{14}$-CORTISOL, tRanscortin CAPACITY (HATCHED AREAS), AND PLASMA 17-OHCS (BLACK BARS) DURING ESTROGEN THERAPY.

prior to the study and were apparently free of cancer, the values were: transcortin binding of $\mathrm{C}^{14}$ cortisol, $94 \pm 2.9$ per cent; transcortin capacity, $23 \pm 3.5$ per cent; and the plasma 17-OHCS levels, $19 \pm 5 \mu \mathrm{g}$ per $100 \mathrm{ml}$. The values for a group (III) of 9 women (ages 39 to 74) seen in Buffalo were: transcortin binding of $\mathrm{C}^{14}$-cortisol, $93 \pm 3.4$ per cent; transcortin capacity, $23 \pm 5.1$ per cent; and the plasma 17-OHCS levels, $23 \pm$ $10 \mu \mathrm{g}$ per $100 \mathrm{ml}$. A comparison of the various values among the groups studied revealed a statistically significant difference in the transcortin binding of $\mathrm{C}^{14}$-cortisol between the normal subjects and groups I and II $(p<0.01)$ and a possible significant difference with group III $(0.02<$ $\mathrm{p}<0.05)$. No significant differences were found in the transcortin capacities. The plasma 17OHCS were higher in the patients with cancer of the breast than in normal subjects. There were no significant differences in the values found with the plasma of women with spontaneous menopause and those with surgically induced menopause.

The effects of estrogens, testosterone and other steroids on transcortin levels. It has been shown previously that the administration of adequate doses of estrogens (stilbestrol, ethinyl estradiol, Premarin) to patients causes an increase in the concentration of plasma transcortin concomitant with an increase in the plasma 17-OHCS levels $(2,3)$. In an attempt to find out how soon following the administration of estrogens these changes occur and for how long they persist, the transcortin levels were determined in a group of 25 patients given estrogens for varying periods of time. A few representative cases are shown in Table I and Figure 2. The estrogens administered were stilbestrol ( 1 to $5 \mathrm{mg}$ three times daily), ethinyl estradiol ( $0.5 \mathrm{mg}$ daily) and Premarin (2.5 to $10 \mathrm{mg}$ daily). It appears that within a few days following the beginning of adequate estrogen therapy the transcortin binding of $\mathrm{C}^{14}$-cortisol and transcortin capacity increased followed by a rise in 17-OHCS levels. Often there were increases in the percentage of $\mathrm{C}^{14}$-cortisol bound before a change in the transcortin capacity was detectable. Thus, in 12 of the subjects the transcortin binding of $\mathrm{C}^{14}$-cortisol and capacity rose by the third day. The former value rose from a mean of $90 \pm$ 3.4 per cent to $96 \pm 2.2$ per cent and the latter changed from $23 \pm 3.2$ per cent to $16 \pm 2.0$ per cent. The mean value for the plasma $17-\mathrm{OHCS}$ remained unchanged: $15 \pm 4 \mu \mathrm{g}$ per $100 \mathrm{ml}$. In the other subjects either no changes had occurred by the third day or the increased transcortin concentration was accompanied by rises in the 17OHCS levels. By the fifth to seventh day the further increases in the transcortin binding of $\mathrm{C}^{14}$ 
TABLE II

Transcortin levels in postpartum patients

\begin{tabular}{|c|c|c|c|c|c|c|c|c|c|}
\hline \multirow[b]{2}{*}{ Subject } & \multicolumn{3}{|c|}{1 Hour postpartum } & \multicolumn{3}{|c|}{2 Days postpartum } & \multicolumn{3}{|c|}{5 Days post partum } \\
\hline & $\begin{array}{l}\mathrm{C}^{14}- \\
\text { cortisol } \\
\text { bound }\end{array}$ & $\begin{array}{l}\text { Binding } \\
\text { capacity }\end{array}$ & $\begin{array}{c}17- \\
\text { OHCS }\end{array}$ & $\begin{array}{l}\mathrm{C}^{14}- \\
\text { cortisol } \\
\text { bound }\end{array}$ & $\begin{array}{l}\text { Binding } \\
\text { capacity }\end{array}$ & OHCS & $\begin{array}{l}\mathrm{C}^{14}- \\
\text { cortisol } \\
\text { bound }\end{array}$ & $\begin{array}{l}\text { Binding } \\
\text { capacity }\end{array}$ & $\begin{array}{l}17- \\
\text { OHCS }\end{array}$ \\
\hline & $\%$ & $\%$ & $\mu g \%$ & $\%$ & $\%$ & $\mu g \%$ & $\%$ & $\%$ & $\mu g \%$ \\
\hline M.N. & 90 & 16 & 22 & 95 & 16 & & 98 & 20 & 7 \\
\hline D.M. & 90 & 18 & 28 & 96 & 26 & 6 & 88 & 18 & 19 \\
\hline N.P. & 96 & 8 & 43 & 94 & 14 & 36 & 92 & 15 & 35 \\
\hline M.J. & & & & 94 & 16 & 13 & 94 & 19 & 13 \\
\hline J.J. & 93 & 16 & 24 & 86 & 14 & 43 & 91 & 15 & 23 \\
\hline V.S. & 87 & 10 & 47 & 96 & 20 & 32 & 98 & 18 & 24 \\
\hline M.S. & 93 & 13 & 47 & 97 & 4 & 19 & 95 & 15 & 30 \\
\hline B. $T$. & 98 & 10 & 15 & 86 & 16 & 48 & 99 & 13 & 9 \\
\hline U.U. & 92 & 14 & 29 & 94 & 17 & 22 & 92 & 17 & 19 \\
\hline M.H. & 92 & 12 & 69 & 96 & 12 & 40 & 98 & 16 & 34 \\
\hline A.T. & 92 & 14 & 80 & & & & 96 & 24 & 17 \\
\hline B.R. & 89 & 11 & 45 & & & & & & \\
\hline B.M. & & & & & & & 94 & 16 & 15 \\
\hline P.M. & & & & 98 & 16 & 15 & & & \\
\hline Mean values & 92 & 13 & 41 & 94 & 16 & 27 & 95 & 17 & 20 \\
\hline
\end{tabular}

cortisol and capacity were invariably accompanied by increases in the 17-OHCS levels in all patients studied. The increase in the transcortin concentration and that of the 17-OHCS persisted during prolonged estrogen treatment. The withdrawal of the estrogen treatment resulted in a fall in the transcortin concentration usually within a week in patients who had received stilbestrol for a short period of time, but persisted for at least 10 days to 2 weeks in patients on prolonged stilbestrol treatment.

The administration of $2.5 \mathrm{mg}$ of Premarin daily for as long as 18 days failed to raise the transcortin or 17-OHCS levels. On the other hand, the daily administration of $10 \mathrm{mg}$ of Premarin resulted in a definite increase in the transcortin binding of $\mathrm{C}^{14}$-cortisol and transcortin capacity and elevated plasma 17-OHCS. The mean control values for five elderly females (ages 62 to 74 ) were: transcortin binding of $\mathrm{C}^{14}$-cortisol, 90 per cent ; transcortin capacity, 22 per cent; and plasma 17OHCS, $22 \mu \mathrm{g}$ per $100 \mathrm{ml}$. In two of the subjects $17-\mathrm{OHCS}$ and transcortin levels were elevated within two days, and in all the subjects the levels were increased within a week following the daily administration of $10 \mathrm{mg}$ of Premarin.

TABLE III

Transcortin levels in plasma determined on undiluted and diluted samples

\begin{tabular}{|c|c|c|c|c|c|c|}
\hline \multirow[b]{3}{*}{ Conditions } & \multicolumn{2}{|c|}{ Undiluted } & \multicolumn{4}{|c|}{ Diluted $(1: 5)$} \\
\hline & Sample 1 & Sample 2 & \multicolumn{2}{|c|}{ Sample 1} & \multicolumn{2}{|c|}{ Sample 2} \\
\hline & $\mathrm{C}^{14}-\mathrm{co}$ & bound & $\begin{array}{l}\text { C14-cortisol }^{14} \text { bound } \\
\end{array}$ & $\begin{array}{c}\text { Binding } \\
\text { capacity }\end{array}$ & $\begin{array}{l}\mathrm{C}^{14} \text {-cortisol } \\
\text { bound }\end{array}$ & $\begin{array}{l}\text { Binding } \\
\text { capacity }\end{array}$ \\
\hline Normal plasma & 98 & 97 & $\begin{array}{l}\% \\
92\end{array}$ & $\begin{array}{l}\% \\
20\end{array}$ & $\begin{array}{l}\% \\
94\end{array}$ & $\begin{array}{l}\% \\
28\end{array}$ \\
\hline Pregnancy plasma & 98 & 98 & 95 & 11 & 98 & 14 \\
\hline Normal $(\mathrm{N})$ vs pregnancy $(\mathrm{P})$ & $\begin{array}{l}\text { N } 99 \\
\text { P } 99\end{array}$ & $\begin{array}{l}97 \\
99\end{array}$ & $\begin{array}{l}90 \\
95\end{array}$ & $\begin{array}{l}20 \\
11\end{array}$ & $\begin{array}{l}96 \\
98\end{array}$ & $\begin{array}{l}22 \\
15\end{array}$ \\
\hline Normal plasma & 98 & 97 & 90 & 27 & 94 & 28 \\
\hline Estrogen plasma & 98 & 99 & 98 & 11 & 99 & 8 \\
\hline Normal vs estrogen (E) & $\begin{array}{l}\text { N } 99 \\
\text { E } 99\end{array}$ & $\begin{array}{l}97 \\
99\end{array}$ & $\begin{array}{l}92 \\
96\end{array}$ & $\begin{array}{r}20 \\
7\end{array}$ & $\begin{array}{l}98 \\
99\end{array}$ & $\begin{array}{l}24 \\
10\end{array}$ \\
\hline Pregnancy vs estrogen & & $\begin{array}{l}\text { P } 98 \\
\text { E } 99\end{array}$ & & & $\begin{array}{l}99 \\
99\end{array}$ & $\begin{array}{r}15 \\
9\end{array}$ \\
\hline
\end{tabular}


TABLE IV

The effects of dilution of plasma on transcortin binding of $C^{14}$-cortisol and capacity

\begin{tabular}{|c|c|c|c|c|c|c|}
\hline \multirow[b]{2}{*}{ Subject } & \multirow[b]{2}{*}{ Conditions } & \multicolumn{2}{|c|}{ Diluted $(1: 5)$} & \multicolumn{2}{|c|}{ Diluted $(1: 10)$} & \multirow[b]{2}{*}{$\begin{array}{c}\text { 17-OHCS } \\
\text { Plasma }\end{array}$} \\
\hline & & $\begin{array}{l}\mathrm{C}^{14} \text {-cortisol } \\
\text { bound }\end{array}$ & $\begin{array}{l}\text { Binding } \\
\text { capacity }\end{array}$ & $\begin{array}{l}\text { Ci4_cortisol } \\
\text { bound }\end{array}$ & $\begin{array}{l}\text { Binding } \\
\text { capacity }\end{array}$ & \\
\hline & & $\%$ & $\%$ & $\%$ & $\%$ & $\mu \mathrm{g} / 100 \mathrm{ml}$ \\
\hline S.R. & Normal & 86 & 19 & 72 & 30 & 24 \\
\hline R.S. & Normal & 87 & 25 & 74 & 29 & 16 \\
\hline L.P. & Leukemia & 78 & 27 & 62 & 36 & 30 \\
\hline H.S. & Estrogen-treated & 99 & 12 & 96 & 20 & 55 \\
\hline R.F. & Pregnancy & 98 & 10 & 97 & 14 & 34 \\
\hline
\end{tabular}

The highest transcortin binding of $\mathrm{C}^{\mathbf{1 4}}$-cortisol and transcortin capacity were 98 and 12 per cent, respectively. The highest 17-OHCS level was 46 $\mu \mathrm{g}$ per $100 \mathrm{ml}$. Elevation of plasma transcortin and 17-OHCS levels were seen in all patients receiving stilbestrol or ethinyl estradiol in the dosage employed. Three patients with cancer of the breast received $16 \alpha$-estradiol dipropionate ( $5 \mathrm{mg}$ three times weekly i.m.) and no changes were seen either in the transcortin or 17-OHCS levels. The administration of 3,4-bis (3-allyl-4-hydroxyphenyl)hexane, a weak estrogen, in doses of 15 to $30 \mathrm{mg}$ orally daily to three postmenopausal women (ages 36 to 49 ), did not change the transcortin binding or the 17-OHCS levels.

The administration of $17 \alpha$-methyl-19-nortestosterone (30 mg daily orally) also failed to cause changes when administered for as long as 36 days. The administration of testosterone propionate $(100$ $\mathrm{mg}$ i.m. three times weekly) to three subjects failed to change the transcortin and 17-OHCS levels significantly, even when administered for as long as 76 days. The administration of large doses (100 mg i.m. three times weekly) of testosterone propionate to 15 additional subjects, including 10 postmenopausal women with cancer of the breast, and $2 \alpha$-methyl-dihydrotestosterone propionate $(100 \mathrm{mg}$ three times weekly) to three subjects failed to change the transcortin levels significantly. In addition, Patient M. W. (Table I) while on tesosterone therapy received estrogens and, as can be seen, the transcortin levels and the 17-OHCS rose. In Patient $\mathrm{M}$. S. the transcortin binding of $\mathrm{C}^{14}$-cortisol rose somewhat during testosterone therapy, but the transcortin capacity and $17-\mathrm{OHCS}$ in the plasma remained normal or decreased.

Transcortin levels postpartum. Transcortin levels have been shown to be elevated during pregnancy, especially during the last trimester (1).

TABLE $V$

The effects of surgery on transcortin and 17-OHCS levels

\begin{tabular}{|c|c|c|c|c|c|c|}
\hline \multirow[b]{2}{*}{ Subject } & \multicolumn{3}{|c|}{ Control } & \multicolumn{3}{|c|}{ Postoperative } \\
\hline & $\begin{array}{l}\mathrm{C}^{14} \text {-cortisol } \\
\text { bound }\end{array}$ & $\begin{array}{c}\text { Binding } \\
\text { capacity }\end{array}$ & 17-OHCS & $\begin{array}{l}\mathrm{C}^{14} \text {-cortisol } \\
\text { bound }\end{array}$ & $\begin{array}{l}\text { Binding } \\
\text { capacity }\end{array}$ & 17-OHCS \\
\hline & $\%$ & $\%$ & $\mu g \%$ & $\%$ & $\%$ & $\mu g \%$ \\
\hline U.K.* & 94 & 23 & 21 & 78 & 16 & 25 \\
\hline & & & & 64 & 1 & 24 \\
\hline K.L. & 88 & 26 & 12 & 74 & 20 & 30 \\
\hline M.Ho. & 92 & 23 & 10 & 71 & 16 & 26 \\
\hline E.B. & 88 & 20 & 16 & 72 & 9 & 34 \\
\hline M.Ha. & 90 & 25 & 21 & $7 \overline{5}$ & 11 & 34 \\
\hline J.W. & 91 & 23 & 5 & 77 & 16 & 24 \\
\hline D.O. & 99 & 24 & 15 & 72 & 18 & 37 \\
\hline E.D. & 87 & 25 & 9 & 70 & 19 & 34 \\
\hline R.C. & 90 & 32 & 7 & 58 & 4 & 64 \\
\hline N.N. & 85 & 23 & 15 & 68 & 12 & 52 \\
\hline N.P. & 84 & 24 & 10 & 69 & 16 & 43 \\
\hline J.A. & 86 & 22 & 33 & 81 & 24 & 29 \\
\hline
\end{tabular}

* The levels in Subject U.K. were determined following two separate surgical procedures performed on different occasions. 
TABLE VI

The effects of various in vitro cortisol concentrations on the binding of $C^{14}$-cortisol (expressed as per cent bound) by plasma from normal and postoperative subjects and by $H S A$

\begin{tabular}{|c|c|c|c|c|c|c|c|}
\hline \multirow[b]{2}{*}{ Cortisol $(\mu \mathrm{g})$} & \multicolumn{2}{|c|}{ Normals } & \multicolumn{4}{|c|}{ Operated subjects } & \multirow{2}{*}{$\begin{array}{r}1 \% \\
\text { HSA }\end{array}$} \\
\hline & 1 & 2 & 3 & 4 & 5 & 6 & \\
\hline 0.3 & $80[19]^{*}$ & $89[10]$ & $58[64]$ & $72[37]$ & $68[52]$ & $81[29]$ & 22 \\
\hline 1.3 & 55 & 66 & 54 & 54 & 56 & 57 & 22 \\
\hline 2.3 & 49 & 48 & 52 & 42 & 54 & 48 & 21 \\
\hline 4.3 & 44 & 38 & 48 & 26 & 36 & 36 & 20 \\
\hline 7.3 & 40 & 34 & 44 & 22 & 34 & 22 & 19 \\
\hline 11.3 & 35 & 31 & 42 & 19 & 29 & 19 & 18 \\
\hline 15.3 & 32 & 30 & 36 & 20 & 29 & 12 & 18 \\
\hline \multirow[t]{2}{*}{21.3} & 26 & 26 & 36 & 20 & 29 & 10 & 18 \\
\hline & & \multicolumn{6}{|c|}{ Preoperative levels } \\
\hline 0.3 & & & $\begin{array}{l}90[7] \\
58\end{array}$ & $\begin{array}{l}88[15] \\
64\end{array}$ & $85[15]$ & $86[33]$ & \\
\hline
\end{tabular}

* Values in brackets are the 17-OHCS levels in $\mu \mathrm{g} \%$.

The transcortin binding of $\mathrm{C}^{14}$-cortisol and capacity were determined in a group of 14 women 1 hour, 2 days and 5 days postpartum, as well as 6 weeks thereafter (Table II). The transcortin capacity in the immediate postpartum samples continued to be elevated, accompanied by very high 17-OHCS levels in some of the patients. By the fifth day postpartum the values for the transcortin binding of $\mathrm{C}^{14}$-cortisol and capacity had changed little, but the 17-OHCS concentration had decreased 50 per cent when compared to the values obtained 1 hour postpartum. By the sixth week all values had reached normal concentrations. The mean values $( \pm \mathrm{SD}$ ) determined in the plasmas of 18 patients (including the 14 patients studied above) at 6 weeks postpartum were: transcortin binding of $\mathrm{C}^{14}$-cortisol, $91 \pm 3.2$ per cent ; trans- cortin capacity, $24 \pm 3.9$ per cent; and plasma 17 -OHCS, $9 \pm 6.2 \mu \mathrm{g}$ per $100 \mathrm{ml}$.

Comparison of methods. A comparison of the binding of $\mathrm{C}^{14}$-cortisol by plasmas from normal subjects, pregnant women, and subjects treated with estrogens was made by two different techniques. Daughaday and associates $(7,8)$ in their studies failed to find a difference between the first two, using a method somewhat different from ours (undiluted plasma). Accordingly, we determined the binding of the same plasmas by both techniques. Samples 1 and 2 in Table III represent two separate sets of experiments performed with plasmas from different subjects in each experiment. As can be seen (Table III), no difference was observed in the binding of plasmas using Daughaday's method of double dialysis, but defi-

TABLE VII

The effects of ACTH and steroids on the transcortin and 17-OHCS levels

\begin{tabular}{|c|c|c|c|c|c|c|c|c|}
\hline \multirow[b]{2}{*}{ Subject } & \multirow[b]{2}{*}{$\begin{array}{c}\text { Substance } \\
\text { administered }\end{array}$} & \multicolumn{3}{|c|}{ Control } & \multirow{2}{*}{$\begin{array}{l}\text { Time follow- } \\
\text { ing admini- } \\
\text { stration }\end{array}$} & \multicolumn{3}{|c|}{ Post-administration } \\
\hline & & $\begin{array}{l}\mathrm{C}^{14} \text {-cortisol } \\
\text { bound }\end{array}$ & $\begin{array}{l}\text { Binding } \\
\text { capacity }\end{array}$ & $17-\mathrm{OHCS}$ & & $\begin{array}{l}\text { C14-cortisol } \\
\text { bound }\end{array}$ & $\begin{array}{l}\text { Binding } \\
\text { capacity }\end{array}$ & 17-OHCS \\
\hline & & $\%$ & $\%$ & $\mu g \%$ & & $\%$ & $\%$ & $\mu g \%$ \\
\hline C.L. & ACTH & 88 & 16 & 27 & $6 \mathrm{hrs}$ & 69 & 5 & 49 \\
\hline D.S. & ACTH & 65 & 12 & 69 & 6 hrs & 47 & 1 & 161 \\
\hline D.Sc. & $\mathrm{ACTH}$ & 88 & 21 & 14 & $6 \mathrm{hrs}$ & 74 & 10 & 46 \\
\hline H.E. & Intravenous cortisol & 82 & 22 & 17 & $\begin{array}{l}2 \mathrm{hrs} \\
4 \mathrm{hrs} \\
6 \mathrm{hrs}\end{array}$ & $\begin{array}{l}65 \\
55 \\
53\end{array}$ & $\begin{array}{r}11 \\
0 \\
0\end{array}$ & $\begin{array}{r}66 \\
69 \\
118\end{array}$ \\
\hline A.S. & $\begin{array}{l}4 \mathrm{mg} 9 \alpha-\mathrm{Fluoro}- \\
\text { cortisol daily }\end{array}$ & 86 & 16 & 6 & 3 days & 92 & 22 & 1 \\
\hline S.G. & $\begin{array}{l}1 \mathrm{mg} 9 \alpha \text {-Fluoro- } \\
\text { cortisol i.v. } \\
\text { over } 8 \text { hrs }\end{array}$ & 94 & 24 & 11 & $\begin{array}{l}4 \text { days } \\
8 \text { hrs }\end{array}$ & $\begin{array}{l}90 \\
92\end{array}$ & $\begin{array}{l}21 \\
19\end{array}$ & $\begin{array}{r}1 \\
10\end{array}$ \\
\hline
\end{tabular}


nite differences were shown with the use of our method. Even though differences were observed in the transcortin binding of $\mathrm{C}^{14}$-cortisol, the most striking differences were seen in the transcortin capacity. The determination of $\mathrm{C}^{14}$-cortisol binding and transcortin capacity on plasmas diluted $1: 10$ (instead of the usual $1: 5$ ) revealed a definite difference between the plasmas of a pregnant woman and a subject receiving estrogens on one hand, and between those of two normal subjects and a leukemic patient on the other (Table IV).

The effect of surgical stress on transcortin levels. It can be observed that the binding of $\mathrm{C}^{14}$-cortisol and transcortin capacity decreased considerably following surgery, concomitant with a rise in plasma 17-OHCS (Table V). The exception was Patient J. A. who did not show a rise in the plasma steroids following a 1 hour surgical procedure; no change of significance was discerned in transcortin levels. To test further the reduced $\mathrm{C}^{14}$ cortisol binding and transcortin capacity accompanying the rise in plasma $17-\mathrm{OHCS}$ in postoperative patients, the effects of increased in vitro concentrations of cortisol on the binding of $\mathrm{C}^{14}$ cortisol (1) were studied on the plasmas of normal subjects and postoperative cancer patients and in a solution of 1 per cent human serum albumin (HSA).

The latter determinations were performed in order to ascertain the binding exhibited by the HSA, which is thought to be the major binding protein of cortisol when transcortin becomes saturated with the steroid. The results in Table VI show that with increasing concentrations of cortisol the binding of $\mathrm{C}^{14}$-cortisol decreased, follow-

TABLE VIII

The binding of certain $C^{14}$-steroids by human plasma (diluted $1 / 5$ with saline) and albumin (values refer to per cent of $C^{14}$-steroid bound)

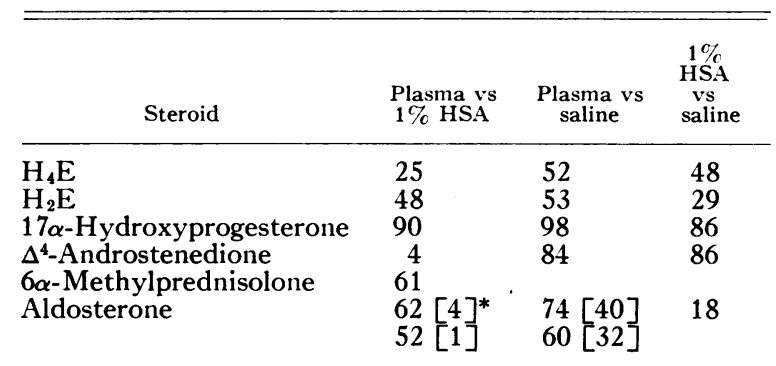

* Figures in brackets refer to the binding of $\mathrm{C}^{14}$-aldosterone caused by the addition of $1 \mu \mathrm{g}$ of cortisol.
TABLE IX

The effects of the addition of various corticosteroids on the binding of $C^{14}$-cortisol*

\begin{tabular}{ccccccc}
\hline $\begin{array}{c}\text { Steroid } \\
\text { added }\end{array}$ & $\mathrm{H}_{2} \mathrm{~F}$ & $\mathrm{H}_{2} \mathrm{E}$ & $\begin{array}{c}\text { Aldo- } \\
\text { sterone }\end{array}$ & $\begin{array}{c}\text { Com- } \\
\text { pound }\end{array}$ & $\begin{array}{c}17- \\
\mathrm{OHPg}\end{array}$ & $\begin{array}{l}\text { Cortico- } \\
\text { sterone }\end{array}$ \\
\hline$\mu g$ & & & & & & \\
1 & 97 & 98 & 90 & 40 & 46 & 72 \\
3 & 96 & 96 & & & & \\
5 & 95 & 94 & 79 & & & \\
10 & 92 & 90 & 70 & & & \\
20 & 89 & 87 & & & &
\end{tabular}

* Values refer to the percentage of $\mathrm{C}^{14}$-cortisol bound and represent the mean of at least four determinations.

The binding of $\mathrm{C}^{14}$-cortisol exhibited by the plasma was 97 per cent, with a transcortin capacity of 27 .

ing in general the pattern shown in Figure 1. The binding of $\mathrm{C}^{14}$-cortisol exhibited by HSA is small but of high capacity, as evidenced by the low decreases in binding with increasing concentrations of cortisol. As can be seen (Table VI), binding capacity was decreased in postoperative patients (see first paragraph under Results).

Effects of ACTH and corticosteroids. Administration of ACTH intravenously (40 units over a period of 6 hours) to patients with cancer resulted in elevated $17-\mathrm{OHCS}$, causing a decreased $\mathrm{C}^{14}$-cortisol binding and transcortin capacity (Table VII). The same was true when a patient with cancer was given cortisol intravenously. The small changes observed in the binding upon the addition of $1 \mu \mathrm{g}$ of cortisol, seen in some patients with cancer given $\mathrm{ACTH}$ or following surgery, in face of a fairly high percentage of $\mathrm{C}^{\mathbf{1 4}}$-cortisol bound, are of interest. The administration of $9 \alpha$-fluorocortisol resulted in insignificant changes in transcortin binding of $\mathrm{C}^{14}$-cortisol and transcortin capacity. One might not expect a change in the binding of $\mathrm{C}^{14}$-cortisol or in the transcortin capacity when the 17-OHCS levels decrease slightly or do not change, as occurred following the administration of $9 \alpha$-fluorocortisol.

In Table VIII is shown the binding by plasma or 1 per cent $\mathrm{HSA}$ of various $\mathrm{C}^{14}$-steroids. In addition, plasma was dialyzed against HSA in order to cancel the effects of the plasma albumin on the binding (1). This procedure showed that $\Delta^{4}$-androstenedione is predominantly bound to the serum albumin and that transcortin shows little affinity for the dihydro $\left(\mathrm{H}_{2} \mathrm{E}\right)$ and tetrahydro $\left(\mathrm{H}_{4} \mathrm{E}\right)$ derivatives of cortisone, aldosterone and $6 \alpha$-methyl-prednisolone. In the case of $\mathrm{C}^{14}$-aldos- 
TABLE $\mathrm{X}$

Transcortin levels in lymph and plasma of subjects with cancer

\begin{tabular}{|c|c|c|c|c|c|c|}
\hline \multirow[b]{2}{*}{ Subject } & \multicolumn{3}{|c|}{ Lymph } & \multicolumn{3}{|c|}{ Plasma } \\
\hline & $\begin{array}{l}\text { C14-cortisol }^{14} \text { bound }\end{array}$ & $\begin{array}{l}\text { Binding } \\
\text { capacity }\end{array}$ & 17-OHCS & $\begin{array}{l}\mathrm{C}^{14} \text {-cortisol } \\
\text { bound }\end{array}$ & $\begin{array}{c}\text { Binding } \\
\text { capacity }\end{array}$ & 17-OHCS \\
\hline & $\%$ & $\%$ & $\mu g \%$ & $\%$ & $\%$ & $\mu g \%$ \\
\hline B.I. & 64 & 25 & 15 & 81 & 15 & 31 \\
\hline N.S. & 76 & 16 & 17 & 80 & 16 & 22 \\
\hline R.B. & 80 & 27 & 14 & 78 & 13 & \\
\hline L.Y. & 58 & 18 & 13 & 75 & 17 & \\
\hline L.N. & 62 & 18 & 10 & 76 & 20 & 9 \\
\hline L.M. & 64 & 20 & 15 & & & \\
\hline W.M. & 70 & 24 & 10 & 76 & 16 & 18 \\
\hline L.A. & 91 & 15 & 23 & 96 & 15 & 9 \\
\hline A. W. & 74 & 20 & 22 & 78 & 24 & 6 \\
\hline E.S. & 63 & 13 & 28 & & & \\
\hline A.F. & 64 & 31 & 9 & & & \\
\hline C.L. & 86 & 38 & 10 & & & \\
\hline B. H. & 82 & 36 & 14 & & & \\
\hline \multirow[t]{2}{*}{ D.R. } & 62 & 44 & 11 & & & \\
\hline & 66 & 30 & 19 & & & \\
\hline Mean values & 71 & 25 & 15 & 80 & 17 & 16 \\
\hline
\end{tabular}

terone, added cortisol easily displaced the former from its binding sites. As can be seen from Table VIII, of all the steroids studied, only $17 \alpha$-hydroxyprogesterone $(17-\mathrm{OHPg})$ was bound to the same extent by plasma as is cortisol but was bound more extensively by human serum albumin than was cortisol. Competition experiments between various steroids, including some of the major metabolites of cortisol, revealed that only corticosterone, compound S (11-deoxycortisol) and $17 \alpha$-hydroxyprogesterone are good competitors for the binding sites (Table IX). One $\mu \mathrm{g}$ of estriol or of cortisone failed to change the binding of $\mathrm{C}^{14}$-cortisol using the standard test. When tetrahydrocortisol or tetrahydrocortisone was added in concentrations of 1 to $20 \mu \mathrm{g}$, no change in the binding of $\mathrm{C}^{14}$-cortisol occurred. The dihydro derivatives of cortisol or cortisone and aldosterone had a minor effect when present in very large concentrations.

The binding of $C^{14}$-cortisol by lymph. The determination of $\mathrm{C}^{14}$-binding and transcortin capacity was performed on lymph obtained from the thoracic ducts of patients with advanced cancer. From Table $\mathrm{X}$ it can be seen that the lymph, on the average, contained transcortin and 17-OHCS in concentrations somewhat lower than those seen in the plasmas of the same subjects.

The mean concentration of total protein in ten lymph fluids was $3.35 \mathrm{~g}$ per $100 \mathrm{ml}$. Examination of these fluids by paper electrophoresis re- vealed the following mean values: 33 per cent of albumin, 12 per cent of $\alpha_{1}$-globulin, 11 per cent of $\alpha_{2}$-globulin, 16 per cent of $\beta$-globulin, and 28 per cent of $\gamma$-globulin. The mean total protein concentration in the sera of these patients was $5.92 \mathrm{~g}$ per $100 \mathrm{ml}$. Paper electrophoretic analysis of the sera revealed 39 per cent albumin, 9 per cent $\alpha_{1^{-}}$ globulin, 13 per cent $\alpha_{2}$-globulin, 20 per cent $\beta$-globulin, and 19 per cent $\gamma$-globulin.

The binding of $C^{14}$-cortisol by erythrocytes. A study was made of the binding of $\mathrm{C}^{14}$-cortisol by erythrocytes in subjects given estrogens, in order to determine whether the increased binding exhibited by the plasma is also shown by the red blood cells. The binding was determined by dialyzing a 10 per cent suspension of red blood cells against saline. Even though there was an increase in the binding of $\mathrm{C}^{14}$-cortisol (control binding 0 to 10 per cent) to as high as 46 per cent, the addition of $1 \mu \mathrm{g}$ of cortisol abolished all the binding of $\mathrm{C}^{14}$-cortisol ( 0 to 4 per cent).

Transcortin changes in a subject with Addison's disease. A subject with known Addison's disease and with no demonstrable 17-OHCS levels in his blood or urine was taken off cortisone therapy for a period of 4 days. The patient was then given stilbestrol ( $1 \mathrm{mg}$ three times daily for 4 days) and the transcortin binding of $\mathrm{C}^{14}$-cortisol and capacity were determined. The binding of $\mathrm{C}^{14}$-cortisol by the control (before estrogen administration) plasma was 98 per cent, with a transcortin ca- 
pacity of 22 per cent, whereas following the administration of the estrogen the binding was 98 per cent, with a capacity of 6 per cent, indicating a definite effect of estrogen on the transcortin concentration in this patient. The 17-OHCS levels remained at zero during the stilbestrol administration.

\section{DISCUSSION}

The data of the present study extend our observations on the effect of estrogens on the plasma transcortin levels in human subjects. The results indicate that rises in transcortin binding and capacity precede the elevation of $17-\mathrm{OHCS}$ in the plasma, suggesting that the increases in the corticosteroid levels observed in conditions with high transcortin levels (pregnancy, estrogen administration) may be due to the inability of the body to metabolize transcortin-bound cortisol with resultant increase in plasma corticosteroid levels. The rises in the transcortin levels induced by estrogens occurred as early as 3 days after commencement of therapy and, although observed with all known active estrogens given, they depended on the dose of the steroid administered. Thus, $2.5 \mathrm{mg}$ of Premarin daily failed to induce a rise, whereas $10 \mathrm{mg}$ did. On the other hand, as little as $3 \mathrm{mg}$ daily of stilbestrol or $0.5 \mathrm{mg}$ daily of ethinyl estradiol produced definite elevations of transcortin levels. It should be pointed out that on the basis of bioassay the following equivalents have been shown: $1.25 \mathrm{mg}$ of Premarin has the activity of 600 to 800 rat units, $1 \mathrm{mg}$ of stilbestrol, 1,500 rat units, and $0.1 \mathrm{mg}$ of ethinyl estradiol, 1,200 rat units (9). From the data shown it would appear that a minimum of 5,000 rat units per day must be administered in order to induce a demonstrable increase in transcortin concentration. The increased transcortin levels returned to normal concentrations within 1 to 2 weeks following cessation of effective estrogen therapy, with the 17-OHCS concentrations declining to normal levels soon after. Herrmann, Schindl and Bondy (10) have recently reported the failure of $5 \mathrm{mg}$ of Premarin to significantly alter levels of plasma cortisol or their response to ACTH infusion, while it significantly lowered urinary excretion of adrenal steroids. These authors implied that the decreased catabolism of cortisol may be due to increased amounts of protein binding of cortisol in plasma.
These observations are borne out by some of the data presented in this paper and by previous observations (1-3). In addition, recently published data $(3,11,12)$ substantiate the hypothesis advanced by us $(1,2)$ that the changes in cortisol metabolism seen during estrogen administration are due to changes in the plasma levels of transcortin.

The values, higher than those seen in normal subjects, observed for the transcortin binding of $\mathrm{C}^{14}$-cortisol in postmenopausal women with various stages of cancer of the breast may be due to the higher concentrations of transcortin, especially when considered in conjunction with the higher plasma 17-OHCS observed in these patients. At present it is difficult to state whether these increases are due to age, sex, or the disease of the patients. Further studies are necessary for clarification of this point. It is interesting to note that elevated levels of serum protein-bound iodine and possibly of serum thyroxine-binding protein have been observed in patients with progressive metastatic carcinoma of the breast (13).

In pregnant women the transcortin levels and the $17-\mathrm{OHCS}$ continued to be elevated 5 days postpartum but returned to normal 6 weeks postpartum.

Of the many steroids studied, only the known active estrogens were capable of inducing concomitant increases in transcortin and 17-OHCS levels. The changes in transcortin capacity induced by estrogens in an Addisonian subject without any demonstrable plasma or urinary 17OHCS would seem to indicate that adrenocortical function is not necessary for the estrogens to cause increased concentrations of transcortin. The binding of $\mathrm{C}^{14}$-cortisol by erythrocytes in vivo was similar to that previously described (14) and was not greatly changed by the administration of estrogens, even though the slight increase in the binding observed may be due to some trapped plasma or binding of small amounts of transcortin to the red blood cells.

Testosterone propionate, $17 \alpha$-methyl-19-nortestosterone, and $2 \alpha$-methyl-dihydrotestosterone propionate were incapable of producing any significant changes in the concentrations of transcortin or 17-OHCS. In addition, testosterone was not able to prevent the changes in transcortin concentration induced by estrogen therapy while the patient was 
receiving large doses of testosterone. In a few instances slight increases were seen during therapy with very large doses of testosterone, changes which may possibly be due to conversion of the androgen to estrogens, as has been reported by others $(15,16)$. The failure of steroids other than estrogens to cause a rise in the transcortin levels points to a specificity of action of these steroids. This is of note, especially in view of the finding that during the administration of large doses of testosterone, stilbestrol was able to cause an increase in the transcortin capacity.

Rises in the levels of 17-OHCS induced by $\mathrm{ACTH}$, stress, and infusion of cortisol caused great decreases in transcortin binding of $\mathrm{C}^{14}$ cortisol and in transcortin capacity due to saturation of the protein with cortisol, which probably occurred at levels of 20 to $40 \mu \mathrm{g}$ per $100 \mathrm{ml}$. With high plasma $17-\mathrm{OHCS}$ levels, the conditions prevailing for the binding of cortisol and transcortin are best depicted in the right half of the "control" curve in Figure 1. As transcortin becomes saturated with cortisol, the percentage of the steroid bound is greatly reduced and additional cortisol causes only small decreases in the amount of steroid bound. The small changes in the $\mathrm{C}^{14}$ cortisol bound upon the addition of $1 \mu \mathrm{g}$ of cortisol seen in some patients with cancer given ACTH or following surgery, in face of a fairly high percentage of $\mathrm{C}^{14}$-cortisol bound before the addition of the extra cortisol, may be due to several factors. It is possible that under the stress of surgery or due to ACTH administration the concentration of transcortin or some other corticosteroidbinding protein increases in the plasma. Furthermore, surgery may result in the appearance in the blood of tissue proteins with affinity to cortisol, akin to the thyroxine-binding protein present in muscle tissue. In addition, surgery or ACTH may induce in cancer patients a shift in the ratio of the various plasma proteins, resulting in an abnormal pattern of steroid-protein interaction.

It is interesting that the unconjugated metabolites of cortisol, dihydro- $\left(\mathrm{H}_{2} \mathrm{E}\right)$ and tetrahydrocortisone $\left(\mathrm{H}_{4} \mathrm{E}\right)$, and dihydro- $\left(\mathrm{H}_{2} \mathrm{~F}\right)$ and tetrahydrocortisol $\left(\mathrm{H}_{4} \mathrm{~F}\right)$ and aldosterone, did not impinge upon the binding capacity of cortisol unless they were present in excess of physiological levels ordinarily found in plasma. Similarly, when tetrahydrocortisol or tetrahydrocortisone was administered intrave- nously, the transcortin binding of $\mathrm{C}^{14}$-cortisol and transcortin capacity did not change in spite of the greatly elevated plasma 17-OHCS levels (17). Only corticosterone, 11-deoxycortisol (compound S) and $17 \alpha$-hydroxyprogesterone seem capable of effectively competing with cortisol for the binding sites on transcortin. From the results in Table IX it appears that steroids of the pregnane series with a $\Delta^{4}$-3-keto group and a $17 \alpha$-hydroxy-20keto group have great affinity for transcortin and that an $11 \beta$-hydroxyl, and especially 11 -keto, group may actually interfere with the binding. These results confirm, in essence, the findings of Daughaday and Mariz (5) regarding the inhibition of the binding of $\mathrm{C}^{14}$-cortisol by various steroids. Since corticosterone and 11-deoxycortisol are present in much lower concentrations than cortisol, and since $17 \alpha$-hydroxyprogesterone has not been demonstrated in human blood, it would appear that under normal conditions transcortin primarily binds cortisol.

The appearance of transcortin in lymph might be due to transcortin which may have left the circulation and is returning via the lymph or it may be due to synthesis of transcortin in a system drained by the lymph. It is interesting to note that the concentration of $\alpha_{1}$-globulin in the lymph was of about the same magnitude as that in the serum of the cancer patients. Since transcortin is found in the $\alpha_{1}$-globulin fraction, it is not surprising to find that the binding exhibited by the lymph fluids was not much lower than that found with plasma. Even though some of the other globulins were present in higher concentrations in the lymph than in the serum, these proteins have been shown to have little affinity for cortisol (14). It should be pointed out, however, that the lymph in our studies was obtained from patients with advanced cancer and these findings may not be applicable to normal subjects. The possible presence of transcortin in some body fluids (synovial, pleural) and its absence in spinal fluid is indicated in the work of Daughaday and co-workers (7).

Daughaday and associates, in earlier work ( 7 , 8 ), failed to find a difference in the binding of labeled cortisol between normal plasma and that obtained from pregnant women or subjects receiving large doses of estrogens. They utilized undiluted plasma in equilibrium dialysis and in a competition or double dialysis, wherein plasma from 
pregnant women or subjects receiving estrogens was dialyzed in the same system with normal plasma, but definite differences were demonstrated, using their system of dialysis as well as ours, when diluted plasma was used. Again, we attributed Daughaday's failure to show a difference between normal and pregnant plasma, and plasma of estrogen-treated subjects, to the high equilibrium constant of transcortin associated with the use of a high protein concentration.

Daughaday and Mariz's conclusion, based on more recent work (5), that there are two corticosteroid-binding globulins in the plasma of pregnant women or of subjects treated with estrogens, is open to another interpretation. They "compared the binding of cortisol by four plasmas of individuals with increased estrogenic activity directly to control plasma using (their) standard conditions (double equilibrium dialysis) of cortisol loading ( $0.5 \mu \mathrm{g}$ per $10 \mathrm{ml}$ of plasma $)$ and also using $5.5 \mu \mathrm{g}$ of cortisol per $10 \mathrm{ml}$ of plasma." The ratio of the binding of cortisol by the plasma of test subjects to that of the control subjects increased with the increased cortisol load. Daughaday states that "in such a situation the relative binding of cortisol would be greatest at the lowest level of cortisol loading." This is not the case, however. Let us consider the two sigmoid binding curves shown in Figure 1. At $0.5 \mu \mathrm{g}$ the binding of the two plasmas is nearly identical, but at $5.5 \mu \mathrm{g}$ the ratio of binding is considerably larger than unity. Thus, Daughaday is observing the same phenomenon as we, although expressing it differently. Indeed, we are in complete accord on the facts, which in our opinion, point to the inability of any of the published methods to distinguish two corticosteroid-binding globulins in human plasma.

\section{SUMMARY}

The administration of adequate amounts of estrogens produces increased concentrations of transcortin within 3 to 7 days, followed by a rise in the levels of the 17-hydroxycorticosteroids (17OHCS). These levels declined to normal within 7 to 10 days after cessation of estrogen treatment. The increased concentration of transcortin can be induced by estrogens in the absence of the adrenal gland.

Testosterone propionate, $17 \alpha$-methyl-19-nortes- tosterone and $2 \alpha$-methyl-dihydrotestosterone propionate failed to change the transcortin or 17 OHCS concentrations.

The increased transcortin concentrations in pregnant women had changed little within 5 days postpartum and were normal 6 weeks after delivery.

ACTH, surgical stress, and intravenous cortisol decreased the transcortin binding of $\mathrm{C}^{14}$-cortisol and transcortin capacity.

Lymph fluids contain transcortin and 17-OHCS in slightly lower concentrations than those seen in plasma.

\section{ACKNOWLEDGMENTS}

We wish to acknowledge the cooperation of Dr. Robert Patterson, who supplied us with plasmas from pregnant women, and to thank Dr. Alvin L. Watne for the thoracic lymph.

$\mathrm{C}^{14}$-labeled cortisol, corticosterone, tetrahydrocortisone acetate and dihydrocortisone acetate were generously supplied by the Endocrinology Study Section of the National Institutes of Health; $\mathrm{C}^{14}$-aldosterone was a gift from $\mathrm{Dr}$. G. Farrell and $\mathrm{C}^{14}$-Medrol from Dr. Harold Upjohn of the Upjohn Company. The Addisonian subject was studied through the courtesy of Dr. George F. Koepf. Dr. Emil Kaiser of Armour and Co. supplied 3,4-bis (3 allyl4-hydroxyphenyl)-hexane. The $16 \alpha$-estradiol dipropionate, $17 \alpha$-methyl-19-nortestosterone, and $2 \alpha$-methyl-dihydrotestosterone propionate were supplied by the Cancer Chemotherapy National Service Center.

\section{REFERENCES}

1. Slaunwhite, W. R., Jr., and Sandberg, A. A. Transcortin: A corticosteroid-binding protein of plasma. J. clin. Invest. 1959, 38, 384.

2. Sandberg, A. A., and Slaunwhite, W. R., Jr. Transcortin: A corticosteroid-binding protein of plasma. II. Levels in various conditions and the effects of estrogens. J. clin. Invest. 1959, 38, 1290.

3. Wallace, E. Z., and Carter, A. C. Studies on the mechanism of the plasma 17-hydroxycorticosteroid elevation induced in man by estrogens. J. clin. Invest. $1960,39,601$.

4. Daughaday, W. H. Steroid protein interactions. Physiol. Rev. 1959, 39, 885.

5. Daughaday, W. H., and Mariz, I. K. The binding of steroid hormones by plasma protein in Conference on Biological Activities of Steroids in Relation to Cancer. New York, Academic Press, 1960.

6. Peterson, R. E., Karrer, A., and Guerra, S. L. Evaluation of the Silber-Porter procedure for determination of plasma hydrocortisone. Analyt. Chem. 1957, 29, 144.

7. Daughaday, W. H., Kozak, I., and Biederman, O. Corticosteroid binding globulin activity in body 
fluids and in fetal and maternal plasma (abstract). J. clin. Invest. 1959, 38, 998.

8. Daughaday, W. H. Binding of corticosteroids by plasma proteins. V. Corticosteroid-binding globulin activity in normal human beings and in certain disease states. Arch. intern. Med. 1958, 101, 286.

9. Shorr, E. An evaluation of the clinical applications of the vaginal smear method. J. Mt Sinai Hosp. $1945,12,667$.

10. Herrmann, W. L., Schindl, I. K., and Bondy, P. K. Effect of estrogen on steroid levels in plasma and urine. Proc. Soc. exp. Biol. (N. Y.) 1960, 103, 103.

11. Peterson, R. E., Nokes, G., Chen, P. S., Jr., and Black, R. L. Estrogens and adrenocortical function in man. J. clin. Endocr. 1960, 20, 495.

12. Mills, I. H., Sched1, H. P., Chen, P. S., Jr., and Bartter, F. C. Effect of estrogen administration on metabolism and protein binding of hydrocortisone. J. clin. Endocr. 1960, 20, 515.

13. Carter, A. C., Feldman, E. B., and Schwartz, H. L. Levels of serum protein-bound iodine in patients with metastatic carcinoma of the breast. J. clin. Endocr. 1960, 20, 477.

14. Sandberg, A. A., Slaunwhite, W. R., Jr., and Antoniades, H. N. The binding of steroids and steroid conjugates to human plasma proteins. Recent Progr. Hormone Res. 1957, 13, 209.

15. West, C. D., Damast, B. L., Sarro, S. D., and Pearson, O. H. Conversion of testosterone to estrogens in castrated, adrenalectomized human females. J. biol. Chem. 1956, 218, 409.

16. Baggett, B., Engel, L. L., Balderas, L., and Lanman, $\mathrm{G}$. Conversion of $\mathrm{C}^{\mathbf{1 4}}$-testosterone to $\mathrm{C}^{\mathbf{1 4}}$-estrogenic steroids by endocrine tissues. Endocrinology 1959, 64, 600 .

17. Sandberg, A. A., Slaunwhite, W. R., Jr., and Carter, A. C. Unpublished results. 